\title{
ECONOMIC CRISIS AND SECURITY CONCERNS OF WHOLESALERS IN EASTERN EUROPEAN AND CENTRAL ASIAN COUNTRIES
}

\author{
Ayse Nilgun Balas \\ Virginia State University, Virginia, USA \\ Halil Dincer Kaya \\ Northeastern State University, Oklahoma, USA
}

\begin{abstract}
We examine how the 2008-2009 global crisis affected wholesalers' spending on security and their losses due to theft, burglary, vandalism or arson in Eastern European and Central Asian countries. The results indicate that a similar percentage of wholesalers paid for security pre- and post-crisis. The results also indicate that the wholesalers that paid for security spent less on security post-crisis. A higher percentage of the partnerships and the larger wholesalers spent money on security post-crisis when compared to the pre-crisis period. On the other hand, fewer shareholding firms with shares traded privately and fewer firms with one or more female owners spent money on security post-crisis when compared to pre-crisis. Especially smaller firms, firms that are not part of a larger firm and sole proprietorships spent less on security post-crisis. Also, fewer wholesalers experienced losses due to crime post-crisis when compared to the pre-crisis period. Finally, our results indicate that, after the crisis, crime was seen as less of an obstacle by these firms.
\end{abstract}

Keywords: crime, wholesale, global crisis, financial crisis

DOI: http://dx.doi.org/10.15549/jeecar.v6i2.262

\section{INTRODUCTION}

In this study, we examine the impact of the 2008-2009 global crisis on theft, robbery, vandalism, or arson experienced by wholesalers in Eastern European and Central Asian countries. We also investigate the influence of the crisis on these firms' spending on security. Our main objective is to see whether wholesalers were successful in allocating their funds (i.e. do they spend more or less money on security when a crime is more rampant?).

In times of economic downturn, overall crime levels go up (Ivaschenko et al., 2012). In this study, we examine the role of firm characteristics, such as size, legal type, the gender of owners and top managers, in influencing the level of crime during an economic crisis. Our main goal is to answer the following questions: What type of wholesalers 
are more affected by an economic crisis? Are all wholesalers influenced equally or are some of them influenced more negatively due to theft, burglary, vandalism, or arson? Additionally, we study to what degree these wholesalers perceive crime as an obstacle. Do wholesalers generally perceive theft, arson, vandalism or arson as a bigger obstacle during an economic crisis when compared to other periods? Our objective is to analyze how different types of wholesalers perceive theft, burglary, vandalism or arson during a crisis period versus a no-crisis period. If a crime is more rampant during a crisis period, wholesalers need to focus more on security. During the crisis period, do more wholesalers spend money on security? Also, on average, do they spend more money on security during this period? If wholesalers are successful in allocating their funds, we would observe an increase in the number of firms that spent money on security during the crisis period. We would also witness increased dollar spending on security during this period. In other words, our study examines security spending for the whole sample as well as for different groups of firms based on size and type.

There are several gaps in the current literature this study attempts to fill. First, although wholesalers play an important part in the supply chain, academic research on wholesalers is limited (Gadde, 2014; Samli, 2007). Second, although inventory shrinkage has been studied in the past decades (Zhou \& Piramuthu, 2017), to the best of our knowledge, none of the existing literature specifically addresses inventory shrinkage due to theft, robbery, vandalism, or arson in wholesalers. Shrinkage has implications on the profitability and survival of wholesalers. Third, the role of the economic crisis on shrinkage due to theft, robbery, vandalism, or arson has not been previously studied, although economic conditions impact property crime rates. This paper attempts to fill these three gaps in the literature by empirically analyzing data collected from Eastern European and Central Asian countries. These countries were most negatively affected by the global crisis of 20082009 (Smith \& Swain, 2010). Emerging markets of Eastern Europe and Central Asia have less resources to spend on combating crime compared to the developed markets of Western
Europe and North America. This is especially true when the governments' tax revenues decrease during economic recessions. We choose to examine Eastern European and Central Asian countries as the effects of global crisis on theft, robbery, vandalism, or arson experienced by wholesalers might be more accentuated due to limited government sources to combat crime.

This paper is organized as follows. In section two, we provide a review of the relevant literature. In section three, we describe the characteristics of the data utilized in this study. In section four, the results of the empirical analysis are provided. Section five concludes with a discussion of our results and why they matter.

\section{LITERATURE REVIEW}

Wholesalers are intermediary firms that are involved in all the activities that are directed towards selling products to companies that buy them for resale or business use (Armstrong \& Kotler, 2015, Mroszczyk, 2008). In other words, wholesalers, known also as industrial distributors, are intermediaries between manufacturers and their customers and they perform a significant role in the distribution channel by carrying out the physical movement of goods from manufacturers to retailers (Das, \& Tyagi, 1994; Rosenbloom, 1989; Rosenbloom, \& Warshaw, 1989). They also perform support services such as technical, logistical, informational, and promotional support for the manufacturers and retailers (Das, \& Tyagi, 1994).

Although getting rid of the wholesalers in the supply chain has been advocated for centuries wholesalers continue to exist (Rosenbloom, 2007; Samli, 2007). In recent decades the supply chain management literature has brought up vertical disintermediation, where manufacturers bypass wholesalers and sell directly to retailers, as a threat to the existence of wholesalers (Aldin \& Stahre, 2003; Rosenbloom, 2007). The threat of disintermediation is fostered by the advent of the internet, which assists direct and immediate interaction between suppliers and end-users and reduction of transaction costs (Vandermerwe, 1999). However, the roles 
wholesalers play by providing broad geographical coverage and strong marketing relations with customers coupled with the costly expense manufacturers and retailers need to bear to get rid of wholesalers make it possible for wholesalers to continue to exist (Aldin \& Stahre, 2003).

Wholesalers' role is performing marketing functions for both manufacturers and their customers (Rosenbloom, \& Warshaw, 1989). The main function of wholesalers is improving the efficiency of the distribution system by performing these marketing functions more effectively and efficiently than manufacturers (Alderson, 1949; Childs, 1997; Rosenbloom, \& Warshaw, 1989; Rosenbloom, 2007). Wholesalers perform the function of four types of sorting - sorting out, assorting, apportioning and collecting - more efficiently. They minimize of the total cost of carrying out the physical movement of goods from manufacturers to their customers as a movement of large quantities take advantage of economies of scale (Rosenbloom, 2007). Finally, wholesalers minimize the total requirements as to storage capacity by optimizing storage (Alderson, 1949). Only when the wholesalers provide a special contribution and lower costs they would be kept in the supply chain (Desai, Koenigsberg, \& Purohit, 2004). In recent decades, there have been threats to the survival of wholesalers. First, retailers have gained more power in the supply chain as they become considerably larger than all the other members of supply chain (Dobson, Waterson, \& Davies, 2003). Large retail chains dominate the markets while small and independent retailers perished. As retailers' power in the supply chain increases, wholesalers are faced with escalated pressure to improve their efficiency and effectiveness in order to survive (Lovreta, Končar, \& Stanković, 2015). Second, mergers and acquisitions in manufacturing further reduced the bargaining power of wholesalers in the marketing channels. Third, technologies, such as enterprise resource planning or radio-frequency identification (RFID) made it possible for manufacturers to directly communicate with retailers, which reduced the need for wholesalers. Fourth, the advent of warehousing clubs negatively impacted the wholesalers. Finally, third-party logistic providers' services took away some of the functions originally provided by the wholesalers (Samli, 2007). In order to remain viable, wholesalers "need to adjust and adapt over time to enhance their effectiveness and efficiency" (Rosenbloom, 2007, p. 329). If wholesalers cannot offer superior services at lower costs than other channel members they would cease to exist (Rosenbloom, 2007).

Effective inventory management is key to efficiency for wholesalers (Oballah, Waiganjo, \& Wachiuri, 2015). As in any business with physical inventory, unaccounted merchandise loss due to theft, loss or damage, has been a problem for wholesalers (Cavianato, 1977). The term shrinkage is used in the literature to denote this unaccounted merchandise (Cavianato, 1977). Inventory theft, spoilage, and damage due to vandalism are some of the factors that cause inventory shrinkage (Sahin, \& Dallery, 2009). Inventory theft could be due to internal theft done by employees or external theft done by others during transport (Webb, n.d.). While external theft in retailers is often done by customers (Bamfield, 2004; Berman, Evans \& Chatterjee, 2018; Kohne \& Pekeur, 2014) as in the traditional retail stores the customers are physically present in the store to fulfill their consumption needs, the same is not true for wholesalers (Rekik, 2011). For wholesalers, the external theft or burglary is done during transport (Webb, n.d.) rather than by customers, as customers are not physically present on the premises (Rekik, 2011). The shrinkage is more pronounced during economic downturns (Kajalo \& Lindblom, 2011). The use of RFID technology is suggested to reduce theft as previous studies suggest that RFID usage makes theft more difficult (Fan, Chang, Gu, Yi, \& Deng, 2014; Hassan, Sharda \& Kasiri, 2016; Rekik, 2011; Zhou \& Piramuthu, 2017). RFID allows the wholesalers to accurately monitor inventory to reduce theft and avoid fraud (Lee \& Özer, 2007). Other suggested measures were surveillance cameras, security guards and installation of security devices. However, these measures increase the costs to wholesalers. Shrinkage experienced by wholesalers and the measures to control it decrease the cost efficiency of wholesalers that is required for their survival. 
In this paper, we examine how inventory shrinkage due to theft and vandalism is influenced by the economic crisis experienced as inventory shrinkage has a direct impact on the efficiency of the wholesalers. Property crime rates increase during economic recessions due to lower employment and income levels (Lin, 2008; Machin \& Meghir, 2004; Raphael \& Winter-Ebmer, 2001). The crime rate increase is fueled further by dwindling government social programs for the unemployed and underemployed, and reduced investments in law enforcement, due to shrinking tax revenue (Fajnzylber, Lederman, Loayza, Reuter, Roman \& Gaviria, 2000). Moreover, governments might choose to spend their resources on anti-crisis measures rather than measures to combat crime (Ivaschenko, Nivorozhkin \& Nivorozhkin, 2012).

\section{DATA}

In this study we use the Business Environment and Enterprise Performance Survey (BEEPS), which is a joint initiative of the World Bank and the European Bank for Reconstruction and Development, to examine 29 countries in Eastern Europe and Central Asia. The countries included in the study are Albania, Armenia, Azerbaijan, Belarus, Bosnia and Herzegovina, Bulgaria, Croatia, Czech Republic, Estonia, FYR Macedonia, Georgia, Hungary, Kazakhstan, Kosovo, Kyrgyz Republic, Latvia, Lithuania, Moldova, Mongolia, Montenegro, Poland, Romania, Serbia, Slovak Republic, Slovenia, Tajikistan, Turkey, Ukraine, and Uzbekistan.
In order to examine the impact of the global crisis on wholesalers' security concerns and security spending, we compare the responses in the 2008 survey to the responses in the 2013 survey. In order to compare the same group of countries pre- and post-crisis, we dropped Russia from our 2013 sample. As a result, we compare the same 29 countries pre- and postcrisis.

Here are the four questions in the survey that we focus on: "In fiscal year 2007, did this establishment pay for security, for example equipment, personnel, or professional security services?" "Yes": 1 and "No": 2. "In fiscal year 2007, what percent of this establishment's total annual sales was paid for security, or what was the total annual cost of security?" "In fiscal year 2007, did this establishment experience losses as a result of theft, robbery, vandalism, or arson?" "Yes": 1 and "No": 2. "Are crime, theft, and disorder No Obstacle, a Minor Obstacle, a Moderate Obstacle, a Major Obstacle, or a Very Severe Obstacle to the current operations of this establishment?" "No obstacle": 0, "Minor obstacle": 1, "Moderate obstacle": 2, "Major obstacle": 3 , and "Very severe obstacle": 4.

Table 1 shows the summary statistics for our sample. The results indicate that while the mean score for the question "In fiscal year 2007, did this establishment pay for security, for example equipment, personnel, or professional security services?" was 1.36 in 2008, it was 1.38 in 2013 (i.e. fewer wholesalers spent money on security).

Table 1. Summary Statistics for Wholesalers

\begin{tabular}{|c|c|c|c|c|c|c|}
\hline & \multicolumn{3}{|c|}{2008} & \multicolumn{3}{|c|}{2013} \\
\hline & $\mathrm{N}$ & Mean & Std & $\mathbf{N}$ & Mean & Std \\
\hline \multicolumn{7}{|l|}{ Panel A. } \\
\hline Did the Estab. Pay for Security during Last Year? & 776 & 1.36 & 0.48 & 970 & 1.38 & 0.49 \\
\hline \multicolumn{7}{|l|}{ Panel B. } \\
\hline Percentage of Annual Sales Paid for Security & 208 & 3.68 & 4.84 & 280 & 3.08 & 4.65 \\
\hline \multicolumn{7}{|l|}{ Panel C. } \\
\hline Loss due to Theft, Robbery, Vandalism, or Arson? & 775 & 1.80 & 0.40 & 967 & 1.86 & 0.35 \\
\hline \multicolumn{7}{|l|}{ Panel D. } \\
\hline Are Crime, Theft, and Disorder an Obstacle? & 763 & 1.38 & 1.44 & 966 & 0.59 & 1.03 \\
\hline
\end{tabular}

Note 1: In Panels A and C, "Yes" is 1, "No" is 2.

Note 2: In Panel D, "No obs." is 0, "Minor" is 1, "Moderate" is 2, "Major" is 3, "Very Severe" is 4. 
Panel B illustrates that while the mean score for the question "In fiscal year 2007, what percent of this establishment's total annual sales was paid for security, or what was the total annual cost of security?" was $3.68 \%$ in 2008 , it was $3.08 \%$ in 2013 (i.e. wholesalers spent less money on security in 2013).

Panel $C$ shows that while the mean score for the question "In fiscal year 2007, did this establishment experience losses as a result of theft, robbery, vandalism, or arson?" was 1.80 in 2008, it was 1.86 in 2013 (i.e. fewer wholesalers experienced losses due to crime in 2013).

Panel D demonstrates that while the mean score for the question "Are crime, theft, and disorder No Obstacle, a Minor Obstacle, a Moderate Obstacle, a Major Obstacle, or a Very Severe Obstacle to the current operations of this establishment?" was 1.38 in 2008, it was 0.59 in
2013 (i.e. wholesalers saw crime as less of an obstacle in 2013).

The next section shows the results of our empirical tests (i.e. Mann-Whitney-Wilcoxon tests) that compare the pre-crisis responses to the post-crisis responses.

\section{EMPIRICAL RESULTS}

Table 2 compares pre- and post-crisis responses given to the first question ("In the fiscal year 2007, did this establishment pay for security, for example, equipment, personnel, or professional security services?"). "No" is coded as 2 and "Yes" is coded as 1 . We report the means. We also show the p-values for the Mann-Whitney-Wilcoxon tests that compare the 2008 responses to the 2013 responses.

Table 2. Did the Wholesaler Pay for Security during Last Year?

\begin{tabular}{|l|c|c|c|}
\hline \multicolumn{3}{|c|}{ Wilcoxon Test } & \\
\hline & 2008 & 2013 & p-value \\
\hline all & 1.36 & 1.38 & 0.2228 \\
\hline Employees 5-19 & 1.45 & 1.42 & 0.1204 \\
\hline Employees 20-99 & 1.32 & 1.34 & 0.2988 \\
\hline Employees >99 & 1.22 & 1.04 & 0.0015 \\
\hline part of a larger firm & 1.36 & 1.31 & 0.2555 \\
\hline not part of a larger firm & 1.37 & 1.39 & 0.1557 \\
\hline shareholding firm trading in the stock market & 1.32 & 1.36 & 0.3942 \\
\hline shareholding firm shares traded privately & 1.32 & 1.38 & 0.0124 \\
\hline sole proprietorship & 1.44 & 1.38 & 0.2384 \\
\hline partnership & 1.58 & 1.31 & 0.0249 \\
\hline limited partnership & 1.55 & 1.80 & 0.1385 \\
\hline other & 1.23 & 1.50 & 0.0415 \\
\hline one or more female owner & 1.29 & 1.40 & 0.0031 \\
\hline no female owner & 1.40 & 1.38 & 0.1832 \\
\hline top manager female & 1.36 & 1.43 & 0.1141 \\
\hline top manager not female & 1.36 & 1.37 & 0.3444 \\
\hline firm without an intl recog. quality certification & 1.40 & 1.40 & 0.4747 \\
\hline firm with an intl recog. quality certification & 1.29 & 1.33 & 0.1814 \\
\hline
\end{tabular}

Note: Yes is 1 , No is 2.

For all wholesalers, the mean value of the responses in 2008 is 1.36 , while it is 1.38 in 2013. The difference between the responses in the pre- and post-crisis periods is statistically insignificant ( $p=0.2228)$. That is, for the overall sample of wholesalers a similar number of firms paid for security pre- and post-crisis. 
When we examine different firm size groups (i.e. firms with five-to-nineteen employees, firms with twenty-to-ninety-nine employees, and firms with more than ninety-nine employees), the results indicate that after the crisis, more of the larger firms (i.e. wholesalers with more than ninety-nine employees) paid for security ( $\mathrm{p}=0.0015)$. "Yes" is coded as 1 and "no" is coded as 2, therefore a lower score in 2013 (1.04) compared to a higher score in 2008 (1.22) indicates that more larger sized wholesalers paid for security in the post-crisis period when compared to the pre-crisis period. There are not any significant difference between pre- and post-crisis for other size groups (i.e. wholesalers with five-to-nineteen employees, etc.).

When we investigate different firm groups based on firm's legal status, we are seeing that significantly fewer shareholding firms with shares traded privately $(\mathrm{p}=0.0124)$ and "other" type of firms $(p=0.0415)$ spent money on security post-crisis. On the other hand, significantly more partnerships $(\mathrm{p}=0.0249)$ spent money on security post-crisis.

When we differentiate between wholesalers with respect to the gender of their owners, we find that fewer wholesalers with one or more female owner spent money on security postcrisis when compared to pre-crisis ( $\mathrm{p}=0.0031$ ). On the other hand, we do not see a significant difference for wholesalers with no female owner between pre- and post-crisis $(\mathrm{p}=0.1832)$.

When we examine wholesalers with respect to the gender of their top manager, we are seeing that it does not matter whether the top manager is male or female: For firms with a female top manager or with a male top manager, there is no significant difference between pre- and post-crisis.

Finally, when we differentiate between wholesalers with respect to their holding of an internationally recognized quality certification (i.e. ISO 9000, 9002, 14000, etc.), we are seeing that there is no significant difference between pre- and post-crisis for firms without a certification. Also, there is no significant difference between pre- and post-crisis for firms with a certification.

Table 3 shows the results of the responses given to the second question (i.e. "In the fiscal year 2007, what percent of this establishment's total annual sales was paid for a security, or what was the total annual cost of security?").

Table 3. Wholesaler's Percentage of Annual Sales Paid for Security

\begin{tabular}{|l|r|r|c|}
\hline \multicolumn{3}{|c|}{ Wilcoxon Test } & \multicolumn{1}{|c|}{ p- } \\
\hline & 2008 & 2013 & \multicolumn{1}{|c|}{ value } \\
\hline all & 3.68 & 3.08 & 0.0054 \\
\hline Employees 5-19 & 3.88 & 3.19 & 0.0127 \\
\hline Employees 20-99 & 3.38 & 2.65 & 0.1140 \\
\hline Employees >99 & 3.76 & 2.60 & 0.1155 \\
\hline part of a larger firm & 2.72 & 3.85 & 0.4592 \\
\hline not part of a larger firm & 3.84 & 2.98 & 0.0028 \\
\hline shareholding firm trading in the stock market & 5.91 & 2.50 & 0.2421 \\
\hline shareholding firm shares traded privately & 3.13 & 2.78 & 0.1161 \\
\hline sole proprietorship & 5.86 & 4.13 & 0.0393 \\
\hline partnership & 6.00 & 5.50 & 0.5000 \\
\hline limited partnership & 2.27 & 1.00 & 0.2357 \\
\hline other & 2.38 & 11.00 & 0.0742 \\
\hline one or more female owner & 3.92 & 2.65 & 0.0239 \\
\hline no female owner & 3.56 & 3.23 & 0.0372 \\
\hline top manager female & 4.43 & 2.85 & 0.0539 \\
\hline top manager not female & 3.53 & 3.13 & 0.0206 \\
\hline firm without an intl recog. quality certification & 3.87 & 3.03 & 0.0109 \\
\hline
\end{tabular}




\begin{tabular}{|c|c|}
\hline firm with an intl recog. quality ce & 0.2178 \\
\hline $\begin{array}{l}\text { We are seeing that, for all wholesalers, the } \\
\text { ean value of the responses in } 2008 \text { was } 3.68 \% \\
\text { sales, while it is } 3.08 \% \text { of sales in } 2013 \text {. The } \\
\text { ference between the responses in the pre- } \\
\text { d post-crisis periods is statistically significant } \\
=0.0054) \text {. The wholesalers spent less money } \\
\text { security as a percentage of their annual sales } \\
\text { st-crisis. }\end{array}$ & $\begin{array}{l}\text { groups of firms (i.e. small firms, sole } \\
\text { proprietorships, etc.) drive the overall results. } \\
\text { Interestingly, our results show that the } \\
\text { wholesalers that are in "other" legal status } \\
\text { actually spent more money on security post- } \\
\text { crisis ( } 2.38 \% \text { of sales in } 2008 \text { versus } 11.00 \% \text { of } \\
\text { sales in } 2013 \text {; p=0.0742). This finding is the } \\
\text { opposite of what we see for the whole sample. }\end{array}$ \\
\hline $\begin{array}{l}\text { When we examine the subgroups, we are } \\
\text { seeing that the difference between pre- and } \\
\text { post-crisis is not statistically significant for } \\
\text { some subgroups. These subgroups are } \\
\text { wholesalers with twenty-to-ninety-nine } \\
\text { employees, wholesalers with more than ninety- } \\
\text { nine employees, firms that are part of a larger } \\
\text { firm, shareholding firms, partnerships, limited } \\
\text { partnerships, and firms without a certification. } \\
\text { Therefore, we can say that the results for certain }\end{array}$ & $\begin{array}{l}\text { Table } 4 \text { shows the wholesalers' losses due to } \\
\text { theft, robbery, vandalism, or arson pre- and } \\
\text { post-crisis. It shows the responses given to the } \\
\text { third question (i.e. "In the fiscal year } 2007 \text {, did } \\
\text { this establishment experience losses as a result } \\
\text { of theft, robbery, vandalism, or arson?"). The } \\
\text { survey codes "yes" as } 1 \text { and "no" as } 2 \text {. Fewer } \\
\text { wholesalers experienced losses due to crime } \\
\text { post-crisis when compared to pre-crisis. The } \\
\text { mean value is } 1.80 \text { in } 2008 \text { versus } 1.86 \text { in } 2013 \\
\text { ( } p=0.0006) \text {. }\end{array}$ \\
\hline
\end{tabular}

Table 4. Any Losses due to Theft, Robbery, Vandalism, or Arson?

\begin{tabular}{|c|c|c|c|}
\hline \multicolumn{4}{|l|}{ Wilcoxon Test } \\
\hline & 2008 & 2013 & $\begin{array}{c}\mathrm{p}- \\
\text { value }\end{array}$ \\
\hline all & 1.80 & 1.86 & 0.0006 \\
\hline Employees 5-19 & 1.85 & 1.87 & 0.2515 \\
\hline Employees 20-99 & 1.79 & 1.85 & 0.0467 \\
\hline Employees $>99$ & 1.68 & 1.76 & 0.1246 \\
\hline part of a larger firm & 1.81 & 1.85 & 0.2200 \\
\hline not part of a larger firm & 1.80 & 1.86 & 0.0008 \\
\hline shareholding firm trading in the stock market & 1.83 & 2.00 & 0.0743 \\
\hline shareholding firm shares traded privately & 1.77 & 1.85 & $<0.0001$ \\
\hline sole proprietorship & 1.89 & 1.91 & 0.3256 \\
\hline partnership & 1.85 & 1.83 & 0.4321 \\
\hline limited partnership & 1.83 & 2.00 & 0.1598 \\
\hline other & 1.80 & 1.77 & 0.4183 \\
\hline one or more female owner & 1.80 & 1.83 & 0.1852 \\
\hline no female owner & 1.80 & 1.87 & 0.0006 \\
\hline top manager female & 1.80 & 1.87 & 0.0352 \\
\hline top manager not female & 1.80 & 1.85 & 0.0034 \\
\hline firm without an intl recog. quality certification & 1.81 & 1.86 & 0.0062 \\
\hline firm with an intl recog. quality certification & 1.79 & 1.84 & 0.0671 \\
\hline
\end{tabular}

Note: Yes is 1 , No is 2.

When we examine different subgroups, we are seeing that only in some subgroups (except for wholesalers with 5-19 employees, wholesalers with more than 99 employees, 
firms that are part of a larger firm, sole proprietorships, partnerships, limited partnerships, "other" legal status firms, and firms with one or more female owner), there were fewer firms experiencing losses due to crime post-crisis. The overall finding of a smaller loss after the crisis is driven by certain groups of firms (i.e. midsized firms, shareholding firms, etc.).

Table 5 compares the pre- and post-crisis responses given to the fourth question (i.e. "Are crime, theft, and disorder No Obstacle, a Minor Obstacle, a Moderate Obstacle, a Major Obstacle, or a Very Severe Obstacle to the current operations of this establishment?"). The survey codes "no obstacle" as 0 , "minor obstacle" as 1 , "moderate obstacle" as 2, "major obstacle" as 3, and "very severe obstacle" as 4.

The table shows that the wholesalers saw crime, theft, and disorder as less of an obstacle after the crisis. The mean value for all firms is 1.38 in 2008, while it is 0.59 in 2013 ( $\mathrm{p}<0.0001$ ). In other words, in the earlier survey, the average respondent saw crime, theft, and disorder as a "Minor" to "Moderate" obstacles for their business. In the later survey, these issues were seen as almost no obstacle to the firms' operations. The table shows that, for all firm size groups and firm types (except for the "other" legal status firms), this finding is valid.

Table 5. Are Crime, Theft, and Disorder an Obstacle?

\begin{tabular}{|c|c|c|c|}
\hline \multicolumn{4}{|c|}{ Wilcoxon Test } \\
\hline & 2008 & 2013 & p-value \\
\hline all & 1.38 & 0.59 & $<0.0001$ \\
\hline Employees 5-19 & 1.33 & 0.61 & $<0.0001$ \\
\hline Employees 20-99 & 1.38 & 0.54 & $<0.0001$ \\
\hline Employees $>99$ & 1.52 & 0.63 & $<0.0001$ \\
\hline part of a larger firm & 1.24 & 0.69 & 0.0036 \\
\hline not part of a larger firm & 1.40 & 0.58 & $<0.0001$ \\
\hline shareholding firm trading in the stock market & 1.23 & 0.09 & 0.0065 \\
\hline shareholding firm shares traded privately & 1.33 & 0.60 & $<0.0001$ \\
\hline sole proprietorship & 1.64 & 0.55 & $<0.0001$ \\
\hline partnership & 1.32 & 0.55 & 0.0205 \\
\hline limited partnership & 1.54 & 0.00 & 0.0043 \\
\hline other & 1.07 & 1.00 & 0.4326 \\
\hline one or more female owner & 1.34 & 0.67 & $<0.0001$ \\
\hline no female owner & 1.43 & 0.56 & $<0.0001$ \\
\hline top manager female & 1.53 & 0.67 & $<0.0001$ \\
\hline top manager not female & 1.35 & 0.58 & $<0.0001$ \\
\hline firm without an intl recog. quality certification & 1.38 & 0.60 & $<0.0001$ \\
\hline firm with an intl recog. quality certification & 1.39 & 0.59 & $<0.0001$ \\
\hline
\end{tabular}

Note: "No obs." is 0, "Minor" is 1, "Moderate" is 2, "Major" is 3, "Very Severe" is 4.

Table 6 shows the results of the binary logistic regression that explains whether the wholesaler paid for security during the previous year.

Paid $=\mathrm{c} 0+\mathrm{c} 1$ (crisisvspostcrisis $)+\mathrm{c} 2($ size $)+$ c3(partofalarger) + c4(type $)+$ c5(femaleowner $)+c 6$ (topmanagerfemale $)+$ c7(intlcertification) $+\varepsilon t$

The results show that, similar percentages of wholesalers spent money on security during the crisis and the post-crisis periods after controlling for several variables (i.e. size, 
whether the firm is part of a larger firm, type, whether the firm has a female owner, whether the top manager is female, and whether the firm has an internationally recognized quality certification). The regression coefficient for "crisis vs post-crisis" is 0.0358 ( $\mathrm{p}=0.7383$ ).

On the other hand, "size" has a significant impact on the probability of firms' spending on security. The coefficient for "size" is 0.6334 $(p<0.0001)$. Larger firms were more likely to spend money on security. This finding is in line with Table 1 . The results also show that the firm "type" is an important determinant of firms' propensity to spend money on security. The coefficient for "type" is -0.1211 ( $\mathrm{p}=0.0229)$. This is also in line with Table 1 (partnerships and proprietorships are more likely to spend money on security.

Table 6. Binary Logistic Regression Predicting Whether the Wholesaler Paid for Security During Last Year

\begin{tabular}{|l|c|c|}
\hline Independent variables & \multicolumn{2}{|c|}{ Paid vs Not Paid for Security } \\
\hline & Coefficient & $p$-value \\
\hline Intercept & -0.1501 & 0.7414 \\
\hline crisis vs post-crisis & 0.0358 & 0.7383 \\
\hline size & 0.6334 & $<0.0001$ \\
\hline part of a larger & -0.0009 & 0.9959 \\
\hline type & -0.1211 & 0.0229 \\
\hline female owner & -0.0282 & 0.3947 \\
\hline top manager female & 0.0205 & 0.7733 \\
\hline intl certification & -0.0219 & 0.5356 \\
\hline LR Chi-Square & 95.21 & $<0.0001$ \\
\hline $\mathrm{N}$ & & 1746 \\
\hline
\end{tabular}

Table 7 shows the results of the logistic regression that explains whether crime, theft, and disorder was a larger obstacle during the crisis.

Obstaclesize $=\mathrm{c} 0+\mathrm{c} 1$ (crisisvspostcrisis $)+$ $\mathrm{c} 2$ (size) $+\mathrm{c} 3$ (partofalarger) + c4(type) + c5(femaleowner) + c6(topmanagerfemale $)+$ c7(intlcertification) $+\varepsilon t$

The results show that, after controlling for several variables, crime was a smaller obstacle during the post-crisis period when compared to the crisis period. In other words, in line with Table 5, crime was a larger obstacle during the crisis when compared to the post-crisis period. The regression coefficient for "crisis vs postcrisis" is $-0.7575(\mathrm{p}<0.0001)$.
The results also show that "size" has a significant impact on the size of an obstacle. The coefficient for "size" is $0.0814 \quad(p=0.0423)$. Crime, theft, and disorder was a larger obstacle for larger wholesalers. This is in line with Table 5. The results also show that whether or not the firm has a female owner has a significant impact on the size of an obstacle. The coefficient for "female owner" (i.e. equal to 1 if the firm has at least one female owner, equal to 2 if the firm has no female owner) is 0.0335 ( $\mathrm{p}=0.0666)$. The wholesalers that did not have any female owner saw crime, theft, and disorder as a larger obstacle when compared to the wholesalers that had at least one female owner. 
Table 7. Regression Predicting Whether Crime, Theft, and Disorder Was A Larger Obstacle During the Crisis

\begin{tabular}{|l|c|c|}
\hline Independent variables & \multicolumn{2}{|c|}{ Larger Obstacle vs Smaller Obstacle } \\
\hline & Coefficient & p-value \\
\hline Intercept & -0.1501 & 0.7414 \\
\hline crisis vs post-crisis & 0.0358 & 0.7383 \\
\hline size & 0.6334 & $<0.0001$ \\
\hline part of a larger & -0.0009 & 0.9959 \\
\hline type & -0.1211 & 0.0229 \\
\hline female owner & -0.0282 & 0.3947 \\
\hline top manager female & 0.0205 & 0.7733 \\
\hline intl certification & -0.0219 & 0.5356 \\
\hline LR Chi-Square & 95.21 & $<0.0001$ \\
\hline $\mathrm{N}$ & & 1746 \\
\hline
\end{tabular}

\section{DISCUSSION AND CONCLUSION}

This study provides insight into the role of the global crisis on wholesalers' security spending and their losses attained due to theft, burglary, vandalism or arson. The developments in the recent decades, such as increasing power of retailers and manufacturers, emergence of technologies diminishing the role of wholesalers, advent of warehouse clubs, and third-party logistics companies fulfilling some of the roles of wholesalers, have impacted the bargaining power of wholesalers in the supply chain (Lovreta et al., 2015; Samli, 2007). In order to survive, wholesalers need to focus on cost efficiencies and inventory management is key in achieving that (Oballah, Waiganjo, \& Wachiuri, 2015). Controlling shrinkage plays an important role on the bottom line of wholesalers. However, money spent on security measures to control shrinkage negatively impacts the cost efficiency of wholesalers.

As stated previously, there is a lack of research on wholesalers although they are an important part of the supply chain (Gadde, 2014; Samli, 2007). This is one of the first studies that examine shrinkage due to crime experienced by wholesalers. Our sample consists of 29 Eastern
European and Central Asian countries as we expect that the crime rates in these countries would be more affected by the adverse effects of economic crisis.

We have reported four central empirical findings. First, our results indicate that a higher percentage of larger-sized wholesalers paid for security after the economic crisis when compared to the pre-crisis period. This result might be due to the financial strength of largersized wholesalers. That is, larger-sized wholesalers have the financial resources to strengthen their security although the environmental conditions do not warrant an urgency for it. Another significant result of this study was on the role of female ownership on security spending. Our results suggest that fewer wholesalers with the female owner(s) spent money on security after the crisis, while the same wasn't true for wholesalers with male owners. This result is interesting and further research is needed to undercover the reason behind this finding. Another area that had a significant difference in security spending before and after the economic crisis is the legal status of the wholesalers. The results show that fewer shareholding firms with shares traded privately and "other" types of wholesalers spent 
money on security after the economic crisis, while more partnerships spent money on security after the crisis. These results might be due to the financial strength of different types of firms based on legal status. While partnerships might be able to diffuse the expense among their partners, privately traded firms might not. Privately traded firms are small businesses where the owners/managers make business and financial decisions based on their impact on their personal wealth, and they may have shorter expected life (Ang, 1992). We do not have much information on the wholesalers categorized as "other," therefore we are not able to provide more conclusions on the reasons why fewer of them spent less money on security after the crisis.

Second, our results indicate that, overall, wholesalers spent less money on security as a percentage of their annual sales after the economic crisis. This result is not surprising as after an economic crisis less property crime is observed (Ivaschenko et al., 2012). Moreover, previous research indicates increased risk awareness during an economic crisis (Blome \& Schoenherr, 2011). However, our results reveal that this result is driven by small-sized wholesalers, wholesalers that are not part of a larger firm, wholesalers that are organized as a sole proprietorship, and wholesalers without an internationally recognized certification. Once again, these characteristics imply wholesalers with limited financial resources. An interesting finding is that wholesalers categorized as "other" in terms of their legal status spent more money on security after the economic crisis. More information on what constitutes the wholesalers to be categorized as "other" is needed to provide a more detailed conclusion.

Third, our results reveal that fewer wholesalers experienced losses due to crime after the economic crisis. This finding supports the prior research that suggests property crimes decrease after the crisis (Ivaschenko et al., 2012). Our study provides detailed information on the characteristics of the firms that experienced fewer losses due to crime. Wholesalers that were mid-sized (20-29 employees), wholesalers that were not part of a larger firm, privately traded wholesalers, and wholesalers with no female owner experienced less property loss. Further research will be helpful in identifying the reasons behind this finding.

Finally, our findings indicate that, after the crisis passed, almost all types of wholesalers described the crime as less of an obstacle. During the crisis, the average wholesaler saw crime, theft, and disorder as a "Minor" to "Moderate" obstacle for the business. After the crisis passed, these issues were seen as almost no obstacle to the firms' operations.

This research has implications for the policymakers and firm managers by providing them the trends in crime and security spending for different wholesale groups based on their characteristics. This research also provides information on whether different wholesale groups are successful in adjusting their spending based on the "crime cycle," which closely relates to the "business cycle." The wholesalers that are found as "unsuccessful" in matching their spending to the actual crime level are advised to make the necessary changes in their policies.

Besides the several possible extensions for further research indicated above, one additional area for further research would be extending this research to developed nations and other emerging markets with different characteristics to test the generalizability of our results.

\section{REFERENCES}

Alderson, W. (1949). Scope and place of wholesaling in the United States. Journal of Marketing, 14(2), 145-155. https://doi.org/10.2307/1247888

Aldin, N., \& Stahre, F. (2003). Electronic commerce, marketing channels and logistics platforms--a wholesaler perspective. European Journal of Operational Research, 144(2), 270-279. https://doi.org/10.1016/S03772217(02)00393-4

Ang, J. (1992). On the theory of finance for privately held firms. The Journal of Entrepreneurial Finance, 1(3), 185-203.

Armstrong, G., \& Kotler, P. (2015). Marketing An introduction. $12^{\text {th }}$ ed. Pearson. 
Bamfield, J. (2004). Shrinkage, shoplifting and the cost of retail crime in Europe: a cross-sectional analysis of major retailers in 16 European countries. International Journal of Retail and Distribution Management, 32(5), p. 235-241. https://doi.org/10.1108/0959055041069923 3

Berman, B., Evans, J. R., and Chatterjee, P. (2018). Retail management - A strategic approach. $13^{\text {th }}$ eds. Pearson.

Blome, C., \& Schoenherr, T. (2011). Supply chain risk management in financial crises-A multiple case-study approach. International Journal of Production Economics, 134(1), 43-57.

https://doi.org/10.1016/j.ijpe.2011.01.002

Cavianato, J.L. (1977). Measuring logistics system loss and damage with a shrinkage approach. Transportation Journal, 16(3), 513.

Childs, N. M., \& Lawler Batista, B. (1994). Japanese food wholesaling: US comparisons and future issues. International Journal of Physical Distribution \& Logistics Management, 24(7), 26-34. https://doi.org/10.1108/0960003941007096 6

Das, C., \& Tyagi, R. (1994). Wholesaler: A decision support system for wholesale procurement and distribution. International Journal of Physical Distribution \& Logistics Management, 24(10), 4-12. https://doi.org/10.1108/0960003941007474 6

Desai, P., Koenigsberg, O., \& Purohit, D. (2004). Strategic decentralization and channel coordination. Quantitative Marketing and Economics, 2(1), 5-22. https://doi.org/10.1023/B:QMEC.000001703 3.09155.12

Dobson, P. W., Waterson, M., \& Davies, S. W. (2003). The patterns and implications of increasing concentration in European food retailing. Journal of Agricultural Economics, 54(1), 111-125.

https://doi.org/10.1111/j.1477-

9552.2003.tb00053.x
Fan, T.-J., Chang, X.-Y., Gu, C.-H., Yi, J.-J., \& Deng, S. (2014). Benefits of RFID technology for reducing inventory shrinkage. International Journal of Production Economics, 147, 659665.

https://doi.org/10.1016/j.ijpe.2013.05.007

Hassan Zadeh, A., Sharda, R., \& Kasiri, N. (2016). Inventory record inaccuracy due to theft in production-inventory systems. International Journal of Advanced Manufacturing Technology, 83(1-4), 623-631. https://doi.org/10.1007/s00170-015-7433-3

Gadde, L.-E. (2014). Distribution network dynamics and the consequences for intermediaries. Industrial Marketing Management, 43(4), 622-629. https://doi.org/10.1016/j.indmarman.2014.0 2.005

Fajnzylber, P., Lederman, D., Loayza, N., Reuter, P., Roman, J., \& Gaviria, A. (2000). Crime and victimization: An economic perspective. Economía, 1(1), pp. 219-302.

Ivaschenko, O., Nivorozhkin, A., \& Nivorozhkin, E. (2012). The role of economic crisis and social spending in explaining crime in Russia: Regional panel data analysis. Eastern European Economics. 50, pp. 21-41.

Kajalo, S., \& Lindblom, A. (2011). An empirical analysis of retail entrepreneurs' approaches to shoplifting. Security Journal, 24(4), pp. 269-282. https://doi.org/10.1057/sj.2010.3

Kohne, C. \& Pekeur, S. W. (2014). An assessment to determine the impact of retail shrinkage on the sustainability and the profitability of $\mathrm{XYC}$ franchise retail stores in the Westerns Cape region of South Africa. Arabian Journal of Business and Management Review, 3 (11), pp. 101-117.

Lee, H., \& Özer, Ö. (2007). Unlocking the value of RFID. Production and Operations Management; Muncie, 16(1), 40-64.

Lin, M.-J. (2008). Does unemployment increase crime? Evidence from U.S. data 1974-2000. The Journal of Human Resources, 43(2), pp. 413-436.

Lovreta, S., Končar, J., \& Stanković, L. (2015). Effects of increasing the power of retail 
chains on competitive position of wholesalers. Acta Polytechnica Hungarica, 12(3), 213-228.

Machin, S., \& Meghir C. (2004). Crime and economic incentives. Journal of Human Resources, 39(4), pp. 958-979.

Mroszczyk, J.W. (2008). Rapporteur's report Wholesale and retail trade sector. Journal of Safety Research, 39, 199-201.

Oballah, D., Waiganjo, E., \& Wachiuri, E.W. (2015). Effect of inventory management practices on organizational performance in public health institutions in Kenya: A case study of Kenyatta National Hospital. International Journal of Education and Research, 3(3), 703-714.

Raphael, S., \& Winter-Ebmer, R. (2001). Identifying the effect of unemployment on crime. Journal of Law and Economics, pp. 259-283.

Rekik, Y. (2011). Inventory inaccuracies in the wholesale supply chain. International Journal of Production Economics, 133(1), 172-181. https://doi.org/10.1016/j.ijpe.2010.02.012

Rosenbloom, B. (1989). The wholesalers' role in performing marketing functions: wholesaler versus manufacturer perceptions. In S. K. Reddy \& L. Pellegrini (Eds.), Retail and Marketing Channels (RLE Retailing and Distribution) (117-137), Routledge, London UK.

Rosenbloom, B. (2007). The wholesaler's role in the marketing channel: Disintermediation vs. reintermediation. The International Review of Retail, Distribution and Consumer Research, 174), 327-339. https://doi.org/10.1080/0959396070150750 0

Rosenbloom, B., \& Warshaw, P.R. (1989). Perceptions of wholesaler functional role prescriptions in marketing channels. European Journal of Marketing, 23(2), 31-46.

Sahin, E., \& Dallery, Y. (2009). Assessing the impact of inventory inaccuracies within a Newsvendor framework. European Journal of Operational Research, 1973), 1108-1118. https://doi.org/10.1016/j.ejor.2008.03.042

Samli, A.C. (2007). American wholesaler. Journal of Marketing Channels, 14(3), 93-101. https://doi.org/10.1300/J049v14n03_06

Smith, A., \& Swain, A. (2010). The global economic crisis, Eastern Europe, and the former Soviet Union: Models of development and the contradictions of internationalization. Eurasian Geography and Economics, 51(1), 1-34. https://doi.org/10.2747/1539-7216.51.1.1

Vandermerwe, S. (1999). The electronic 'gobetween service provider': a new 'middle' role taking centre stage. European Management Journal, 176), 598-608. https://doi.org/10.1016/S02632373(99)00050-X

Webb, R. (n.d.). 7 Risks Wholesalers Must Prepare For. Retrieved December 29, 2018, from http://www.clearrisk.com/riskmanagement-blog/7-risks-wholesalersmust-prepare-for

Zhou, W., \& Piramuthu, S. (2017). Identification shrinkage in inventory management: an RFID-based solution. Annals of Operations Research, 258(2), 285-300. https://doi.org/10.1007/s10479-015-2022-2 


\section{ABOUT THE AUTHORS}

Ayse Nilgun Balas, email: abalas@vsu.edu

Dr. Ayse Nilgun Balas is an Associate Professor of Management and Marketing at Virginia State University. Dr. Balas' research interests include international business, international marketing, exporting, and marketing strategy. She has published academic research papers on the marketing strategy of domestic and international firms in various scholarly academic journals.

Dr. Halil Kaya is a Professor of Finance at Northeastern State University. Dr. Kaya teaches in the MBA and Master of Accounting and Financial Analysis programs. He also teaches undergraduatelevel international finance. His research interests include corporate finance, corporate governance, and entrepreneurial finance. He has over 110 refereed journal articles and over 40 presentations at academic conferences. He has served as the Program Chair and the President of the Kentucky Economic Association. 